\title{
Evaluation of Entamoeba histolytica recombinant phosphoglucomutase protein for serodiagnosis of amoebic liver abscess
}

\author{
Tan Zi Ning ${ }^{1 \dagger}$, Wong Weng Kin ${ }^{1 \dagger}$, Rahmah Noordin ${ }^{2 \dagger}$, See Too Wei Cun ${ }^{1 \dagger}$, Foo Phiaw Chong ${ }^{1 \dagger}$,
} Zeehaida Mohamed ${ }^{3 \dagger}$, Alfonso Olivos-Garcia ${ }^{4 \dagger}$ and Lim Boon Huat ${ }^{1 *}$

\begin{abstract}
Background: Amoebic liver abscess (ALA) is the most frequent clinical presentation of extra-intestinal amoebiasis. The diagnosis of ALA is typically based on the developing clinical symptoms, characteristic changes on radiological imaging and serology. Numerous serological tests have been introduced for the diagnosis of ALA, either detecting circulating amoebic antigens or antibodies. However those tests show some pitfalls in their efficacy and/or the preparation of the tests are costly and tedious. The commercial IHA kit that used crude antigen was reported to be useful in diagnosis of ALA, however high antibody background in endemic areas may cause problems in its interpretation. Thus, discovery of well-defined antigen(s) is urgently needed to improve the weaknesses of current serodiagnostic tests.
\end{abstract}

Methods: Crude antigen of E. histolytica was analysed by 2-DE and Western blot to identify a protein of diagnostic potential for ALA. The corresponding gene of the antigenic protein was then cloned, expressed and the purified recombinant protein was subsequently evaluated for serodiagnosis of ALA in an indirect ELISA format.

Results: Analysis of crude antigen showed that phosphoglucomutase (PGM) has the diagnostic potential. Recombinant PGM (rPGM) showed 79.17\% (19/24) sensitivity and 86.67\% (195/225) specificity in diagnosis of ALA based on the COV of mean +1SD. There was no significant difference between rPGM-ELISA and IHA diagnostic kit in the diagnosis of ALA in terms of sensitivity and specificity at $p$-value $<0.05$.

Conclusion: In conclusion, rPGM-ELISA is found to be useful for serodiagnosis of ALA. Future studies will determine whether rPGM-ELISA also detects antibodies produced in amoebic dysentery and asymptomatic cases.

Keywords: Entamoeba histolytica, Amoebic liver abscess, 2-DE, Western blot, Phosphoglucomutase, Diagnosis, rPGM-ELISA

\section{Background}

Liver abscess is commonly detected by radiological imaging technique, but it cannot differentiate between amoebic and pyogenic liver abscesses. Differential diagnosis depends on clinical grounds and amoebic serology [1]. The serological tests revealed varied sensitivity levels, depending on the presence or absence of invasive disease and the types of invasive disease. Interestingly, more than

\footnotetext{
* Correspondence: limbh493@gmail.com

${ }^{\dagger}$ Equal contributors

'School of Health Sciences, Universiti Sains Malaysia, Kubang Kerian, Kelantan 16150, Malaysia

Full list of author information is available at the end of the article
}

$90 \%$ of patients with amoebic liver abscess (ALA) developed detectable anti-amoebic antibodies at $7-10$ days after onset of symptoms. This augurs well for the development of serodiagnosis against the infection [2-4].

Numerous studies indicated high sensitivity and specificity of crude amoebic antigen e.g. crude soluble antigen and excretory-secretory antigens in capturing amoebic antibodies for diagnosis of ALA [5-8]. However, the pitfalls of crude antigen are the need to maintain $E$. histolytica cultures and the mass production of the antigen, which are costly and tedious. Occasionally, this cocktail antigen preparation reveals false positivity [9]. IHA Cellognost $^{\circledR}$ Amoebiasis Kit (Dade Behring Marburg

\section{() Biomed Central}


GmbH, Germany) that uses crude antigen was reported to be useful in diagnosis of ALA, yet due to the high background in endemic areas, the diagnostic validity varied between $70 \%$ and $90 \%$ among different geographical locations [10-12]. Hence, a standardised serological test based on well-defined antigen(s) is needed to overcome the weaknesses.

Recombinant DNA technology offers large-scale production of defined antigens through prokaryotic expression system. Serodiagnosis of invasive amoebiasis using defined recombinant $E$. histolytica antigens of serine-rich protein (SREHP), Gal/GalNAc-specific lectin and $29 \mathrm{kDa}$ cysteine-rich surface protein has been reported since 1990s [13]. The recombinant protein of SREHP showed sensitivity of $79 \%$ and specificity of $87 \%$ in diagnosis of ALA, yet its overall diagnostic validity was lower than the conventional tests that utilized crude antigen [14]. Even though both recombinant Gal/GalNAc-specific lectin and $29 \mathrm{kDa}$ cysteine-rich surface proteins showed high validity of $\geq 90 \%$ sensitivity and specificity in serodiagnosis of amoebic dysentery and asymptomatic amoebiasis, they were not specific in the diagnosis of ALA $[15,16]$.

Therefore, this study attempted to identify and analyse potential new antigenic protein(s) from crude antigen of E. histolytica using human ALA serum samples. The corresponding gene of the antigenic protein(s) was then cloned and expressed, followed by the diagnostic potential evaluation of the purified recombinant protein in an indirect ELISA format.

\section{Methods}

\section{Human serum}

Positive serum samples were obtained from 24 patients warded in Hospital Universiti Sains Malaysia (HUSM) who were diagnosed with ALA based on clinical symptoms; detectable abscess by ultrasound imaging; and positive serology with a commercial indirect haemagglutination kit, IHA (Cellognost ${ }^{\circledR}$ Amoebiasis Kit, Dade Behring Marburg GmbH, Germany). On the other hand, non-ALA serum samples with IHA seronegative were obtained from 33 patients, in which four serum samples were obtained from patients with pyogenic liver abscess $(n=4)$ whereas the others were obtained from patients infected with pathogens other than E. histolytica, which include enteropathogenic Escherichia coli $(\mathrm{n}=1)$, Shigella sonnei Group D $(\mathrm{n}=1)$, Salmonella spp. $(\mathrm{n}=5)$, Klebsiella pneumoniae $(\mathrm{n}=1)$, Staphylococcus aureus $(\mathrm{n}=1)$, Ascaris lumbricoides $(\mathrm{n}=1)$, Escherichia coli $(\mathrm{n}=2)$, Coagulasenegative Staphylococcus $(\mathrm{n}=1)$, Stenotrophomonas maltophilia $(\mathrm{n}=1)$, Toxoplasma gondii $(\mathrm{n}=9)$ and Helicobacter pylori $(\mathrm{n}=6)$. In this study, all the six $H$. pylori sera were pooled into a single tube because the individual volumes were too little. In addition, a total of 197 blood donor serum samples were obtained from Department of Haematology \& Blood Transfusion Unit at HUSM. All the human serum samples were collected and checked with IHA from the year 2008 onwards and kept at $-20^{\circ} \mathrm{C}$ until used. This study was conducted in accordance with the requirement of Universiti Sains Malaysia Human Research Ethics Committee, USMKK/PPP/JEPeM (213.3. [10]).

\section{Maintenance of E. histolytica and preparation of crude soluble antigen (CSA)}

E. histolytica HM-1:IMSS was axenically cultured and maintained in Diamond's TYI-S-33 medium [17]. For CSA preparation, $10 \times 10^{6}$ of E. histolytica trophozoites were mixed with $500 \mu \mathrm{L}$ complete Lysis-M buffer supplemented with protease inhibitor cocktail (Roche, Germany) and 20 $\mu \mathrm{L}$ of $0.5 \mathrm{M}$ iodoacetamide (Sigma, USA). The mixture was then sonicated (Branson, Mexico) at 10\% amplitude for three cycles of $1 \mathrm{~min}$ sonication with $0.5 \mathrm{sec}$ pulse-on and $0.5 \mathrm{sec}$ pulse-off. The lysate was centrifuged at $10000 \times g$ for $10 \mathrm{~min}$ at $4^{\circ} \mathrm{C}$ to collect the CSA in the supernatant. Subsequently, the protein concentration was estimated using Bradford protein assay [18].

\section{Analysis of CSA antigenic protein profile via SDS-PAGE and Western blotting}

Twenty micrograms of CSA per well was separated by 9\% sodium dodecyl sulfate polyacrylamide gel electrophoresis (SDS-PAGE) using Bio-Rad Mini-Protean III Electrophoresis Cell (Bio-Rad, USA) at a constant current of $25 \mathrm{~mA}$ per gel for about $1 \mathrm{~h}$ and the separated proteins were electroblotted onto a $0.45 \mu \mathrm{m}$ pore-size nitrocellulose (NC) membrane via a semidry transblot apparatus (Bio-Rad, USA) at constant voltage of $15 \mathrm{~V}$ for $45 \mathrm{~min}$. The NC membrane was blocked for $1 \mathrm{~h}$ at RT with $5 \%$ skim milk with $10 \mathrm{mM}$ Tris-buffered saline (TBS), pH 7.2 as the diluent. Subsequently, the NC membrane was cut into multiple strips and incubated with human sera at a dilution of 1:200 in TBS containing $0.1 \%$ Tween 20 (TBST) for $2 \mathrm{~h}$ at RT. The excess serum was removed by washing $(3 \times 5 \mathrm{~min})$ the strips with TBST. Next, the strips were incubated with a monoclonal mouse anti-human IgG conjugated with horseradish peroxidase (HRP) (Invitrogen, USA) at a dilution of 1:6000 for $1 \mathrm{~h}$ at RT. The unbound secondary antibodies were removed by washing $(3 \times 5 \mathrm{~min})$ with $0.1 \%$ TBST. The Western blot signal was detected by enhanced chemiluminescence (ECL) reagent (Roche Diagnostics, Germany), captured using X-ray film (Kodak, USA). The sensitivity and specificity of the antigenic protein was then evaluated based on serum samples collected from ALA cases $(n=24)$, patients with infections other than amoebiasis $(n=33)$ and blood donors $(n=30)$. 


\section{Identification of the antigenic protein via 2-DE and Western blotting}

A 2-DE gel electrophoresis was performed to further separate the antigenic protein band. Proteins of CSA were first fractionated based on their isoelectric point (pI) using 3100 OFFGEL Fractionator (Agilent Technologies, Germany). The ImmobilineTM Dry Strip (GE Healthcare, $\mathrm{UK}$ ) with linear $\mathrm{pH}$ range $3-10$ with a 12 -well setup was used. The fractionation of CSA was performed according to the manual provided by the manufacturer. In brief, the protein sample was prepared by gently mixing $1600 \mu \mathrm{L}$ of OFFGEL stock solution (1.25X) with $400 \mu \mathrm{L}$ of the CSA sample with total protein mass of $2 \mathrm{mg}$. A volume of 150 $\mu \mathrm{L}$ of OFFGEL sample was loaded into each well of IPG strip after gel rehydration with $40 \mu \mathrm{L}$ of IPG strip rehydration buffer. Mineral oil used as cover fluid was pipetted onto the gel strip ends. The sample was focused with a maximum power of $200 \mathrm{~mW}$, maximum current of $50 \mu \mathrm{A}$ and typical voltages ranging from 500 to $4500 \mathrm{~V}$ until 50 $\mathrm{kVh}$ was reached in $\sim 24 \mathrm{~h}$. The typical starting voltages used were from 200 to $1500 \mathrm{~V}$. A volume of $20 \mu \mathrm{L}$ of the fractionated protein sample was mixed with $5 \mu \mathrm{L}$ of $5 \mathrm{X}$ SDS sample buffer without boiling, and subsequently separated by SDS-PAGE. The separated proteins were then transferred onto NC membrane followed by Western blot analysis using pooled and individual ALA or IHA seronegative serum samples at 1:200 dilution.

\section{Mass spectrometry analysis and protein identification}

The antigenic protein band was excised from the 2-D SDSPAGE gel and sent to Australian Proteomic Service for peptide sequencing by mass-spectrometry. At the proteomic facility, protein sample was digested with trypsin and the peptides were extracted and analysed by electrospray ionisation mass spectrometry (ESI-TRAP) using the Ultimate 3000 nano HPLC system (Dionex) coupled to a 4000 Q TRAP mass spectrometer (Applied Biosystems). The mass-spectrometry analysis was performed with two different gel slice samples to ensure reproducibility.

\section{Cloning of selected gene}

Based on the amino acid sequence of the $\sim 70 \mathrm{kDa}$ antigenic protein, the encoding gene was identified. PCR primers were then designed based on the protein coding sequence retrieved from the GenBank (accession number XM_643579) to amplify the gene of interest from $E$. histolytica genomic DNA isolated from $3 \times 10^{6}$ of $E$. histolytica trophozoites using a QIAamp DNA mini kit (QIAGEN GmbH, Germany). The optimum annealing temperature was $52^{\circ} \mathrm{C}$. For cloning into $\mathrm{pET}-14 \mathrm{~b}$ vector, XhoI (CTCGAG) and BamHI (GGATCC) recognition sequences were added to the forward and reverse primers, respectively. The primers sequences used to generate a 1785 bp PCR product were 5'- CCG CTC
GAG ATG GCA CTG AAT AAT TAT ATT AAG-3' forward primer; and 5'- CGC GGA TCC TTA CTC AGC TTT TGG TGG-3' reverse primer. The amplified product with the expected size was cut and extracted from the $1 \%$ agarose gel using QIAGEN gel extraction kit (QIAGEN GmbH, Germany). Before ligation, both the PCR amplified product and pET-14b vector were digested with XhoI and BamHI (Fermentas Life Sciences, USA). The digested products were then purified by PCR purification kit (QIAGEN GmbH, Germany).

Ligation was performed by mixing the digested plasmid and PCR amplified product in the ratio of 1:3 in a final volume of $10 \mu \mathrm{L}$ containing $1 \mathrm{X}$ T4 DNA Ligase buffer, $5 \mathrm{U}$ of T4 DNA Ligase and $\mathrm{dH}_{2} \mathrm{O}$. The ligation mixture was incubated overnight at $4{ }^{\circ} \mathrm{C}$. Next, E. coli XL 1-Blue competent cells were transformed with the ligation mixture by heat-shock method. Colony PCR using T7 promoter primer (5'-TAATACGACTCACTATAGG-3') and T7 terminator primer (5'-GCTAGTTATTGCTCAGCGG-3) was performed to screen for positive transformants, and the positive clones were confirmed by DNA sequencing.

\section{Expression and purification of recombinant antigenic protein}

Recombinant plasmid carrying the open reading frame for the antigenic protein was transformed into expression host (E. coli BL-21 AI strain). The bacteria was grown at $37^{\circ} \mathrm{C}$ until $\mathrm{OD}_{600 \mathrm{~nm}}$ reached 1.2 and protein expression was induced with $0.2 \%(\mathrm{w} / \mathrm{v})$ L-arabinose at $22^{\circ} \mathrm{C}$ for overnight. The recombinant protein was purified using nickel-nitrilotriacetic acid (Ni-NTA) affinity purification method. In brief, $800 \mathrm{~mL}$ of culture were harvested by centrifugation at $1800 \times g, 20 \mathrm{~min}$, at $4^{\circ} \mathrm{C}$. The supernatant was discarded and the cell pellet was mixed and resuspended in $10 \mathrm{~mL}$ of lysis buffer $[50 \mathrm{mM}$ Tris- $\mathrm{HCl}$ ( $\mathrm{pH} 7.5), 300 \mathrm{mM} \mathrm{NaCl}, 10 \mathrm{mM}$ Imidazole and $1 \%$ Triton X-100] supplemented with $7.8 \mu \mathrm{L}$ of $\beta$ mercaptoethanol. The suspension was then sonicated and centrifuged at $1800 \times g, 30 \mathrm{~min}$, at $4^{\circ} \mathrm{C}$. The supernatant was transferred into a clean $15 \mathrm{~mL}$ centrifuge tube. A volume of $100 \mu \mathrm{L}$ of Ni-NTA agarose (QIAGEN, Germany) was mixed with the supernatant and the suspension was then rotated at $4^{\circ} \mathrm{C}$ for $2 \mathrm{~h}$. After that, the suspension was centrifuged at $450 \times g, 2 \mathrm{~min}$, at $4^{\circ} \mathrm{C}$. The supernatant was discarded and the Ni-NTA agarose was washed with $10 \mathrm{~mL}$ of ice-cooled His-Tag washing buffer [50 mM Tris-HCl (pH 7.5), $300 \mathrm{mM} \mathrm{NaCl}$ and $20 \mathrm{mM}$ Imidazole]. The suspension was rotated at $4^{\circ} \mathrm{C}$ for $30 \mathrm{~min}$. The supernatant was discarded and the washing step on Ni-NTA agarose was repeated for another 5 times. In the final washing step, the suspension was centrifuged at $450 \times g, 2 \mathrm{~min}$, at $4^{\circ} \mathrm{C}$ and the supernatant was discarded. The recombinant protein that bound to the Ni-NTA agarose was eluted by $120 \mu \mathrm{L}$ of 
ice-cooled His-Tag elution buffer $[50 \mathrm{mM}$ Tris- $\mathrm{HCl}$ (pH 7.5), $300 \mathrm{mM} \mathrm{NaCl}$ and $200 \mathrm{mM}$ Imidazole] and rotated at $4^{\circ} \mathrm{C}$ for $3 \mathrm{~h}$. The suspension was then centrifuged at $450 \times g, 5 \mathrm{~min}$, at $4^{\circ} \mathrm{C}$ and the concentration of the supernatant (eluted protein) collected in a clean $1.5 \mathrm{~mL}$ micro-centrifuge tube was determined by Bradford protein assay.

\section{Development and evaluation of indirect recombinant antigen based ELISA}

Indirect-ELISA was performed on the human serum samples using the purified recombinant protein based on modifications of method described by Reen [19]. The coating concentration of the antigen for each well of a microtiter plate was $1 \mu \mathrm{g} / \mathrm{mL}$; and the primary and secondary antibody dilutions were 1:50 and 1:250, respectively. In brief, each well of a 96-well flat-bottom microtiter plate (NUNC, Denmark) was coated with $100 \mu \mathrm{L}$ of antigen diluted in $0.1 \mathrm{M}$ bicarbonate buffer ( $\mathrm{pH}$ 9.6). The plate was then covered and incubated overnight in a humid box at $4^{\circ} \mathrm{C}$. Prior to the blocking step, coated plate was equilibrated for $1 \mathrm{~h}$ at room temperature and then each well was rinsed (5 $\times 5 \mathrm{~min}$ ) with $200 \mu \mathrm{L}$ phosphate buffered saline added with $0.05 \%$ Tween-20 (PBST). The plate was blotted against a piece of paper towel after every round of rinsing. After $1 \mathrm{~h}$ in blocking reagent (Roche, Germany), each well was washed with $0.05 \%$ PBST $(5 \times 5 \mathrm{~min})$, followed by another hour of incubation with $100 \mu \mathrm{L}$ of diluted serum samples, performed in duplicate. After another round of washing, $100 \mu \mathrm{L}$ of PBS diluted HRP-conjugated mouse monoclonal anti-human IgG (Invitrogen, USA) was added into the well and incubated for $1 \mathrm{~h}$. Following a final round of washing, $100 \mu \mathrm{L}$ of TMB substrate was added and the plate was incubated in the dark at room temperature for $15 \mathrm{~min}$. The optical densities (OD) were finally read at $450 \mathrm{~nm}$ VersaMax $^{\text {TM }}$ Microplate Reader (Sunnyvale, USA). The and specificity of the recombinant antigen in an indirect ELISA format was then evaluated against the IHA kit using the different categories of serum samples collected. The COV for the indirect ELISA was set at either mean OD value plus one or two standard deviations (SD) from the OD values obtained from 113 IHA seronegative blood donor serum samples.

\section{Statistical analysis}

Statistical analysis was performed with SPSS for Windows version 18.0. The association between the indirect ELISA and IHA in clinical diagnosis of ALA was analysed using chisquare test; if indicated Fisher's exact test was used instead.

\section{Results}

IgG blots of CSA

Immunoblotting results showed that there were three antigenic proteins i.e. $\sim 170 \mathrm{kDa}, \sim 100 \mathrm{kDa}$ and $\sim 70 \mathrm{kDa}$, recognized by individual human ALA serum samples (Figure 1). Based on the 24 human ALA serum samples, the sensitivities of these three antigenic proteins were $70.83 \%, 62.5 \%$ and $70.83 \%$, respectively; while their specificities were $100 \%, 100 \%$ and $96.83 \%$, respectively, when tested against a total of 63 negative control serum samples. The results on the sensitivity and specificity are summarised in Table 1.

\section{2-DE Western blot analysis and protein identification}

Both the $\sim 170 \mathrm{kDa}$ and $\sim 70 \mathrm{kDa}$ proteins revealed almost similar sensitivity and specificity. Since the $\sim 170 \mathrm{kDa}$ was most probably the previously studied lectin antigen [16] and $\sim 100 \mathrm{kDa}$ showed lower sensitivity, hence here, only the $\sim 70 \mathrm{kDa}$ protein was further studied. In 2D-Western blotting analysis, the $70 \mathrm{kDa}$ protein was presented in fraction 7 with $\mathrm{pH}$ between 6.5 and 7.08. Western blot in fraction 7 using two individual human ALA serum samples revealed positive reactivity against the targeted antigenic protein (Figure 2). Mass-spectrometry analysis identified the $\sim 70 \mathrm{kDa}$ antigenic protein as phosphoglucomutase (PGM) of E. histolytica (accession number C4M3Z6) with the protein score of 793 and 19 peptide sequences matched to the amino acid sequence. The score $>55$ indicates identity or extensive homology at a significant level of $\mathrm{p}<0.05$. The total sequence coverage of the protein was reported as $25 \%$.

\section{Expression and purification of the recombinant PGM (rPGM) protein}

The rPGM protein tagged with six consecutive histidine residues was purified using Ni-NTA affinity purification and was evaluated by $9 \%$ SDS-PAGE (Figure 3 ). The result showed that about $50 \%$ of the expressed PGM was present in the soluble fraction (lane 3). In lane 4, it revealed the soluble recombinant protein was successfully purified to apparent homogeneity.

\section{Efficacy of rPGM-ELISA}

The COVs of rPGM-ELISA at mean OD value + 1SD and mean $\mathrm{OD}$ value $+2 \mathrm{D}$ were determined to be 0.25 and 0.32 , respectively. The sensitivity was calculated based on results of 24 human ALA serum samples; while a total of 225 human sera from other infections and blood donors were used for specificity test. Based on the COV of mean $+1 \mathrm{SD}$ and mean $+2 \mathrm{SD}$, the sensitivities of rPGM-ELISA were $79.17 \%(19 / 24)$ and $45.83 \%(11 / 24)$, respectively; while the specificities of the tests were $86.67 \%(195 / 225)$ and $93.78 \%(211 / 225)$, respectively (Table 2). Thus the COV based on mean + 1SD was selected over the COV of mean + 2SD as it showed better sensitivity and specificity in diagnosis of ALA. In comparison with IHA kit, statistical analysis showed that there was no significant difference between rPGM- 


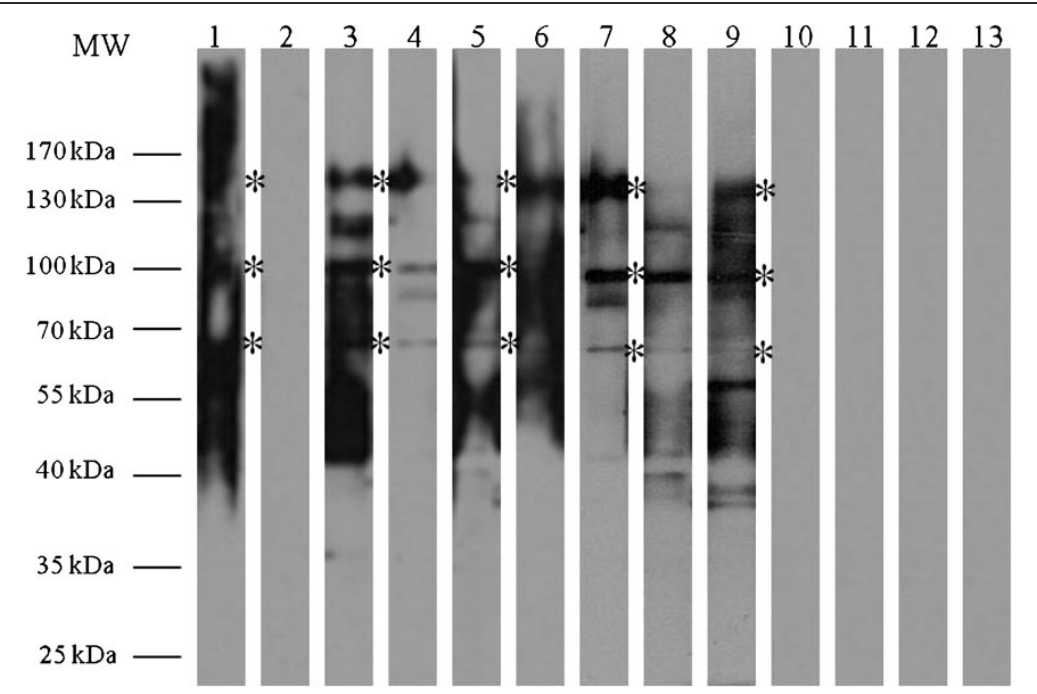

Figure 1 Western blot profile of CSA probed with representative individual human serum. Lane MW: Molecular weight standard (PageRulerTM Prestained Protein Ladder); Lane 1: Pooled human ALA serum; Lane 2: Pooled human IHA seronegative serum; Lanes 3 to 9: Individual human ALA serum; Lanes 10-12: Individual human IHA seronegative serum; Lane 13: TBS control. $\left(^{*}\right)$ indicates the estimated molecular weight of proteins $(\sim 170 \mathrm{kDa}, \sim 100 \mathrm{kDa}$ and $\sim 70 \mathrm{kDa})$.

ELISA and IHA in terms of sensitivity and specificity at p-value $<0.05$ (Table 3).

\section{Discussion}

Conventionally, diagnosis of ALA is confirmed by finding the E. histolytica trophozoites in liver pus aspirate obtained via ultrasound guided percutaneous aspiration biopsy, but the parasites are often absent as most of them are located at the margin on the peripheral of the abscess $[20,21]$. Therefore, serodiagnosis is widely adopted for diagnosis of ALA, detecting either amoebic antigens or antibodies from serum samples. Although numerous commercial antigen detection kits have been developed i.e. TechLab E. histolytica II ELISA (TechLab, Blacksburg, VA), Entamoeba CELISA-PATH (Cellabs Pty Ltd., Brookvale, Australia), Optimum S Entamoeba histolytica antigen ELISA (Merlin Diagnostika, Berheim-Hersel, Germany), Triage parasite panel BIOSATE (diagnostic, San Diego, CA), and ProSpecT Entamoeba histolytica microplate assay (REMEL Inc., Lenexa, KS), only TechLab E. histolytica II ELISA was evaluated for the detection of circulating antigen in ALA patient serum samples [22]. Haque et al. [23] reported that the kit detected Gal/ GalNAc lectin in the ALA patient serum samples with a sensitivity of $96 \%$. However, reports by Parija and Khairnar [24] and Zeehaida et al. [25] revealed lower sensitivities at $50 \%$ and $8.6 \%$, respectively.

Instead of antigen detection, diagnosis of ALA can be performed by detecting circulating antibodies because hepatic amoebiasis raises a strong humoral response, especially immunoglobulin G [26]. Although a variety of serological assays was reported in diagnosis of ALA based on detecting circulating antibodies i.e. IHA, latex agglutination, indirect immunofluorescence, counterimmunoelectrophoresis, gel diffusion, complement fixation and ELISA; IHA and ELISA are still the preferred choices [22]. ELISA is commonly used as the routine diagnostic assay in diagnosis of ALA because it can be developed for in-house use based on different amoebic antigen preparations such as CSA, excretory-secretory antigens, plasma membrane antigens, purified antigenic proteins or recombinant proteins.

The CSA-based ELISA technique has either been used in routine diagnosis of ALA or field screening of amoebiasis $[8,10,27,28]$. In the diagnosis of ALA, CSAbased ELISA was reported to be $100 \%$ sensitive and > $90 \%$ specific $[8,29]$. Excretory-secretory antigens have been reported to be useful in diagnosis of ALA, which

Table 1 Sensitivity and specificity of each potential antigenic protein bands of CSA

\begin{tabular}{|c|c|c|c|c|}
\hline $\begin{array}{l}\text { Molecular weight of } \\
\text { antigenic protein } \\
\text { band }(\mathrm{kDa})\end{array}$ & $\begin{array}{c}\text { Clinically confirmed } \\
\text { human ALA serum } \\
(n=24)\end{array}$ & $\begin{array}{c}\text { Human IHA } \\
\text { seronegative serum } \\
(n=63)\end{array}$ & Sensitivity (\%) & Specificity (\%) \\
\hline 170 & 17 & 0 & 70.83 & 100 \\
\hline 100 & 15 & 0 & 62.5 & 100 \\
\hline 70 & 17 & 2 & 70.83 & 96.83 \\
\hline
\end{tabular}




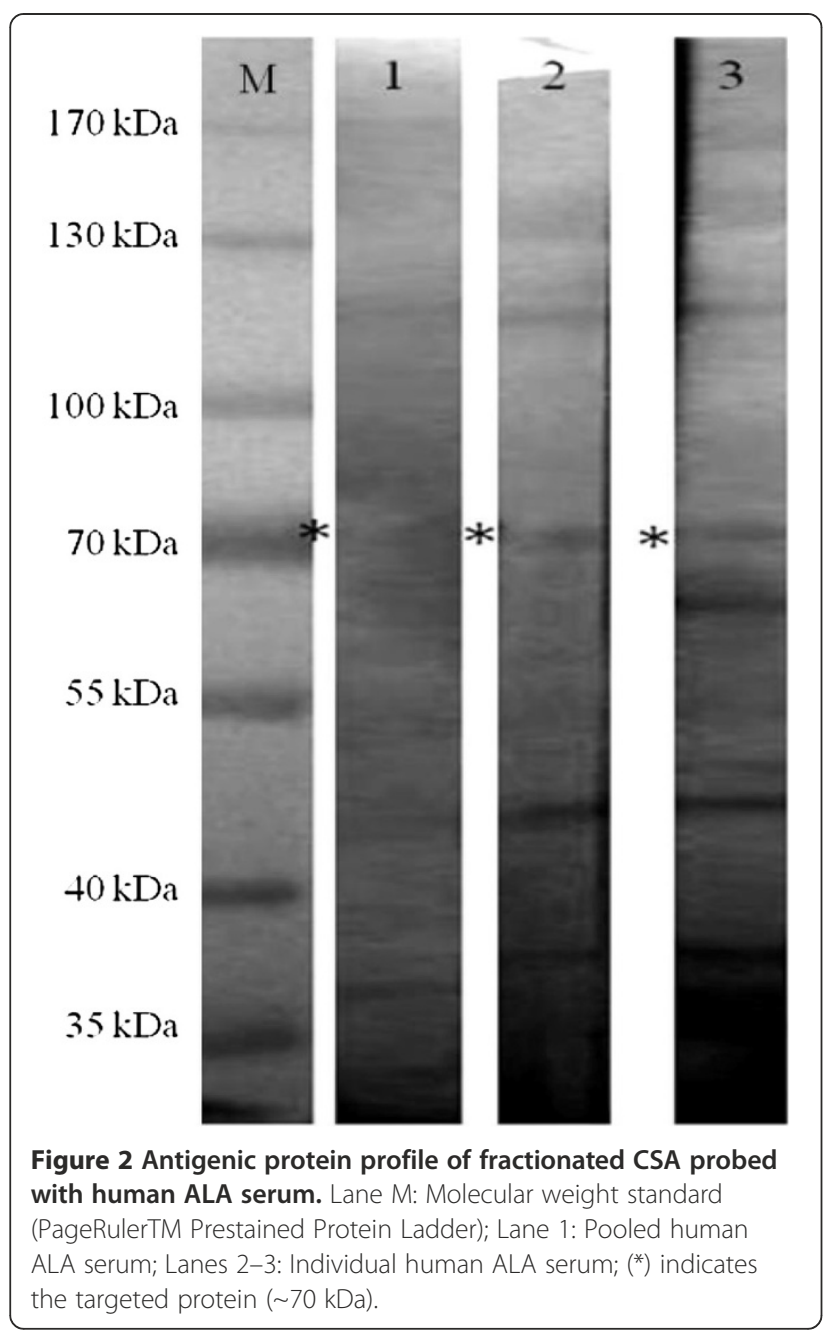

showed sensitivity of $\sim 80 \%$ in Western blot analysis [7,30]. Another ELISA using amoebic plasma membrane antigen for diagnosis of ALA was reported to be $95 \%$ sensitive and 91\% specific against anti-amoebic IgG; while detection of anti-amoebic IgM was $91 \%$ sensitive and $95 \%$ specific [31].

Nonetheless, crude preparations of amoebic antigens produced variable diagnostic efficacies, which may lead to false positive in the diagnosis of ALA. These antigen preparations require maintenance of E. histolytica cultures, which is costly and tedious. Moreover, the proteins are not well-defined; hence the interpretation of results may vary from batch to batch. In this study, analysis of the CSA protein profile showed that most of the antigenic proteins recognized by the human ALA serum antibodies ranged from $25 \mathrm{kDa}$ to $170 \mathrm{kDa}$. Lower percentage (9\%) polyacrylamide gel revealed that the $\sim 170 \mathrm{kDa}, \sim 100 \mathrm{kDa}$ and $\sim 70 \mathrm{kDa}$ protein bands were well recognized by human ALA serum samples. Here, the $\sim 70 \mathrm{kDa}$ protein with $70.83 \%$ sensitivity and $96.83 \%$ specificity was selected for cloning and production of recombinant protein. The $\sim 170 \mathrm{kDa}$ protein also revealed almost similar sensitivity and specificity, but was not selected because it was most probably similar to the previously described lectin surface antigen of $E$. histolytica [16].

Prior to elucidating the identity of the $\sim 70 \mathrm{kDa}$ protein, it was further separated using 2-DE electrophoresis, a widely used technique in biomarker discoveries [32]. Proteins of CSA were fractionated via OFFGEL approach based on pI separation. This approach is advantageous when serum sample is limited. Multiple individual serum samples can be applied on the selected pI protein fraction containing the protein of interest in NC strip blot format, instead of using the whole gel $\mathrm{NC}$ membrane format in the conventional 2D-Western blot.

The $\sim 70 \mathrm{kDa}$ protein in this study was identified as $E$. histolytica PGM by mass-spectrometry analysis. This protein is reported to be involved in the glycolytic pathway of E. histolytica, which catalyses the inter-conversion of glucose 6-phosphate and glucose 1-phosphate. Previously, PGM was used as the gold standard for differentiation between $E$. histolytica and $E$. dispar via isoenzyme electrophoresis together with hexokinase [33]. Interestingly, there is no report on the value of this protein in diagnosis of invasive amoebiasis.

Well-defined antigens such as purified antigenic proteins and recombinant proteins of E. histolytica can overcome some of the setbacks posed by utilization of crude soluble preparations. For instance, purified lectin antigen and purified $29 \mathrm{kDa}$ cysteine-rich surface protein in an ELISA format were reported to be useful for diagnosis of ALA [34,35]. According to Flores et al. (1993), the purified native $29 \mathrm{kDa}$ cysteine-rich surface protein showed $79 \%$ sensitivity and $98 \%$ specificity in the diagnosis of ALA [34]. Several recombinant proteins have been produced such as SREHP, Gal/GalNAc-specific lectin, $29 \mathrm{kDa}$ cysteine-rich surface protein and $40 \mathrm{kDa}$ $\mathrm{NADP}^{+}$-dependent alcohol dehydrogenase (EhADH1) $[13,36]$. Recombinant proteins of SREHP, Gal/GalNAcspecific lectin and $29 \mathrm{kDa}$ cysteine-rich surface protein have been evaluated for diagnosis of ALA. SREHP/MBP fusion protein, which was among the first recombinant proteins used in serodiagnosis of ALA was reported to have a sensitivity and specificity of $74 \%$ and $55 \%$, respectively. Interestingly, its diagnostic validity increased to $79 \%$ and $87 \%$, respectively, after the removal of its MBP component [14]. The validity is almost similar with rPGM protein in the current study, which is $79.17 \%$ sensitive and $86.67 \%$ specific. Recombinant full-length $170 \mathrm{kDa}$ Gal/GalNAc-specific lectin protein has been produced and its validity in diagnosis of ALA was about 91\% sensitivity [16]. Besides, several recombinant fragments of the Gal/GalNAc-specific lectin protein have also been investigated for the diagnosis of ALA. For 


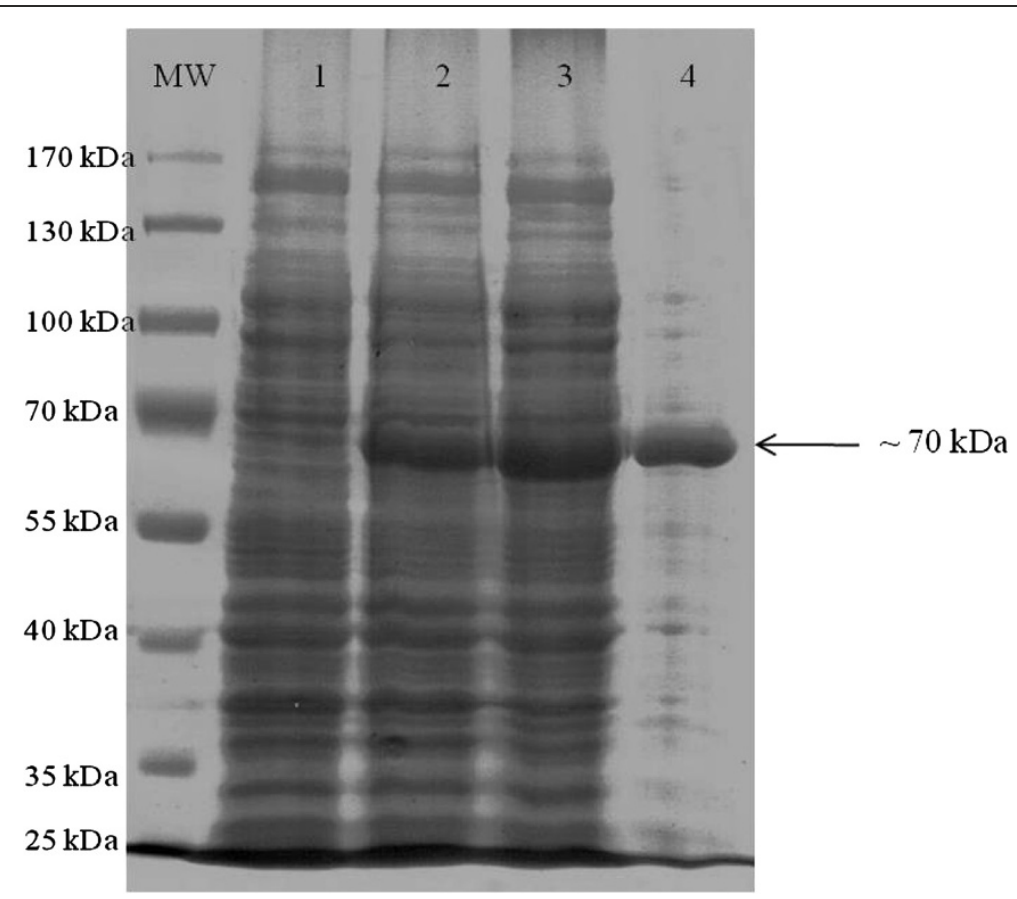

Figure 3 Purified recombinant PGM protein. Lane MW: PageRulerTM Prestained Protein Ladder; Lane 1: Non-induced cell pellet; Lane 2: Induced cell pellet; Lane 3: Induced cell supernatant; Lane 4: Purified protein; Arrow indicates the recombinant PGM protein ( 70 kD).

example, recombinant protein of a truncated immunodominant domain of the Gal/GalNAc-specific lectin protein with $1.85 \mathrm{kbp}$ cDNA insert showed more than $90 \%$ for both sensitivity and specificity [28]. Another study using recombinant Gal/GalNAc-specific lectin-derived protein (LC3) showed $100 \%$ sensitivity in diagnosis of ALA [37]. A study carried out by Tachibana et al. [29] reported that the $150 \mathrm{kDa}$ recombinant intermediate subunit (IgI) of the Gal/GalNAc-specific lectin protein used in diagnosis of ALA was only $8.6 \%$ sensitive. A recombinant $29 \mathrm{kDa}$ cysteine-rich surface protein was also

Table 2 Number of serum sample at different COV settings from different serum test groups using rPGM-ELISA

\begin{tabular}{lccc}
\hline rPGM-ELISA (COV = mean + 1SD) & \multicolumn{2}{c}{$\begin{array}{c}\text { Number of } \\
\text { Serum samples }\end{array}$} & Total \\
\cline { 2 - 3 } & $\mathbf{0 . 2 5}$ & $\mathbf{0 . 2 5}$ & \\
\hline Human ALA serum & 5 & 19 & 24 \\
Other infections human serum & 21 & 7 & 28 \\
Blood donors' serum & 174 & 23 & 197 \\
Total & 200 & 49 & 249 \\
rPGM-ELISA (COV = mean + 2SD) & $<\mathbf{0 . 3 2}$ & $\geq \mathbf{0 . 3 2}$ & \\
Human ALA serum & 13 & 11 & 24 \\
Other infections human serum & 26 & 2 & 28 \\
Blood donors' serum & 185 & 12 & 197 \\
Total & 224 & 25 & 249 \\
\hline
\end{tabular}

developed and evaluated as its purified form showed moderate validity in diagnosis of ALA. The evaluation of this recombinant protein in the diagnosis of ALA showed increment of sensitivity (90\%) compared to its purified native form protein (79\%) [34].

Although several recombinant proteins have been evaluated, they were not specific for diagnosis of ALA because several studies have reported that those recombinant proteins were immunoreactive with serum samples for amoebic dysentery and asymptomatic cases $[15,16,29,38,39]$. In the current study, the novel rPGM protein showed diagnostic validity of $\sim 80 \%$ sensitivity and $\sim 90 \%$ specificity in diagnosis of ALA. The efficacy

Table 3 Comparison between rPGM-ELISA and IHA in terms of sensitivity and specificity in diagnosis of ALA using statistical analysis

\begin{tabular}{|c|c|c|c|c|c|}
\hline \multicolumn{2}{|c|}{ Sensitivity } & \multicolumn{2}{|c|}{ IHA } & \multirow[t]{2}{*}{ Total } & \multirow{2}{*}{$\begin{array}{c}\text { Fisher's Exact Test } \\
\text { (p-value) }\end{array}$} \\
\hline & & .00 & 1.00 & & \\
\hline \multirow[t]{2}{*}{ rPGM-ELISA } & .00 & 0 & 5 & 5 & \multirow[t]{2}{*}{0.620} \\
\hline & 1.00 & 2 & 17 & 19 & \\
\hline \multicolumn{2}{|l|}{ Total } & 2 & 22 & 24 & \\
\hline \multirow{2}{*}{\multicolumn{2}{|c|}{ Specificity }} & \multicolumn{2}{|c|}{ IHA } & \multirow[t]{2}{*}{ Total } & \multirow{2}{*}{$\begin{array}{c}\text { Fisher's Exact Test } \\
\text { (p-value) }\end{array}$} \\
\hline & & .00 & 1.00 & & \\
\hline \multirow[t]{2}{*}{ rPGM-ELISA } & .00 & 181 & 14 & 195 & \multirow[t]{2}{*}{0.638} \\
\hline & 1.00 & 28 & 2 & 30 & \\
\hline \multicolumn{2}{|l|}{ Total } & 209 & 16 & 225 & \\
\hline
\end{tabular}

Note: (.00): Negative; (1.00): Positive. 
of rPGM-ELISA was almost comparable to previously reported recombinant proteins such as SREHP, Gal/ GalNAc-specific lectin and $29 \mathrm{kDa}$ cysteine-rich surface protein, which showed both sensitivity and specificity ranging from $80 \%$ to $100 \%[16,34,39]$.

\section{Conclusion}

In conclusion, the novel rPGM protein used in an indirect ELISA format developed in this study could be useful for in-house routine diagnosis of ALA. Future studies will determine whether rPGM-ELISA also detects antibodies produced in amoebic dysentery and asymptomatic cases.

\section{Consent}

Written informed consents were obtained from the patients for publication of this report.

\section{Competing interests}

The authors hereby declare that they have no competing interests.

\section{Authors' contributions}

All authors contributed to this work. First author, TZN carried out the experiments and drafted the manuscript. All authors were involved in the manuscript preparation. All authors read and approved the final version of the manuscript.

\section{Acknowledgements}

This study was funded by Universiti Sains Malaysia Research University Grant: 1001/PPSK/813044. The first two authors (TZN and WWK) received financial support through the university fellowship and the fifth author (FPC) is a graduate assistant at School of Health Sciences. Besides, we would like to thank the Dean of School of Health Sciences and also the Director of Institute for Research in Molecular Medicine (INFORMM), Universiti Sains Malaysia for the facilities made available.

\section{Author details}

'School of Health Sciences, Universiti Sains Malaysia, Kubang Kerian, Kelantan 16150, Malaysia. ${ }^{2}$ Institute for Research in Molecular Medicine, Universiti Sains Malaysia, Penang 11800, Malaysia. ${ }^{3}$ Department of Medical Microbiology and Parasitology, School of Medical Sciences, Universiti Sains Malaysia, Kubang Kerian, Kelantan 16150, Malaysia. ${ }^{4}$ Departamento de Medicina Experimental, Facultad de Medicina, Universidad Nacional Autónoma de México, México D. F 04510, México.

Received: 25 December 2012 Accepted: 13 March 2013

Published: 21 March 2013

\section{References}

1. Pitt HA: Surgical management of hepatic abscesses. World J Surg 1990, 14:498-504.

2. Mathur S, Gehlot RS, Mohta A, Bhargava N: Clinical profile of amoebic liver abscess. JIACM 2002, 3:367-373.

3. Sharma MP, Ahuja V: Amoebic liver abscess. JIACM 2003, 4:107-111.

4. Wells CD, Arguedas M: Amebic liver abscess. South Med J 2004, 97:673-682.

5. Knappik M, Borner $U$, Jelinek T: Sensitivity and specificity of a new commercial enzyme-linked immunoassay kit for detecting Entamoeba histolytica lgG antibodies in serum samples. Eur J Clin Microbiol Infect Dis 2005, 24:701-703.

6. Robert R, Mahaza C, Bernard C, Buffard C, Senet JM: Evaluation of a new bicolored latex agglutination test for immunological diagnosis of hepatic amoebiasis. J Clin Microbiol 1990, 28:1422-1424.

7. Wong WK, Tan ZN, Othman N, Lim BH, Mohamed Z, Olivos Garcia A Noordin R: Analysis of Entamoeba histolytica excretory-secretory antigen and identification of a new potential diagnostic marker. Clin Vaccine Immunol 2011, 18:1913-1917.
8. Yang J, Kennedy MT: Evaluation of enzyme-linked immunosorbent assay for the serodiagnosis of amebiasis. J Clin Microbiol 1979, 10:778-785.

9. Lotter H, Mannweiler E, Schreiber M, Tannich E: Sensitive and specific serodiagnosis of invasive amebiasis by using a recombinant surface protein of pathogenic Entamoeba histolytica. J Clin Microbiol 1992, 30:3163-3167.

10. del Carmen S-GM, Velazquez-Rojas M, Salgado-Rosas H, Torres-Rasgado E, Perez-Fuentes R, Martinez-Munguia J, Talamas-Rohana P: Seroprevalence of anti-entamoeba histolytica antibodies by IHA and ELISA assays in blood donors from Puebla. Mexico. Arch Med Res 2000, 31:S53-S54.

11. Kraoul L, Adjmi H, Lavarde V, Pays JF, Tourte-Schaefer C, Hennequin C: Evaluation of a rapid enzyme immunoassay for diagnosis of hepatic amoebiasis. J Clin Microbiol 1997, 35:1530-1532.

12. Zeehaida M, Bachok $N$, Hasan $H$ : Analysis of indirect hemagglutination assay results among patients with amoebic liver abscess. Int Med J 2009, 16:195-199.

13. Stanley SL Jr: Progress towards development of a vaccine for amebiasis. Clin Microbiol Rev 1997, 10:637-649.

14. Myung K, Burch D, Jackson TF, Stanley SL Jr: Serodiagnosis of invasive amebiasis using a recombinant Entamoeba histolytica antigen-based ELISA. Arch Med Res 1992, 23:285-288.

15. Ravdin Jl, Jackson TF, Petri WA Jr, Murphy CF, Ungar BL, Gathiram V, Skilogiannis J, Simjee AE: Association of serum antibodies to adherence lectin with invasive amebiasis and asymptomatic infection with pathogenic Entamoeba histolytica. J Infect Dis 1990, 162:768-772.

16. Zhang Y, Li E, Jackson TF, Zhang T, Gathiram V, Stanley SL Jr: Use of a recombinant 170-kilodalton surface antigen of Entamoeba histolytica for serodiagnosis of amebiasis and identification of immunodominant domains of the native molecule. J Clin Microbiol 1992, 30:2788-2792.

17. Diamond LS, Harlow DR, Cunnick CC: A new medium for the axenic cultivation of Entamoeba histolytica and other Entamoeba. Trans $R$ Soc Trop Med Hyg 1978, 72:431-432.

18. Bradford MM: A rapid and sensitive method for the quantitation of microgram quantities of protein utilizing the principle of protein-dye binding. Anal Biochem 1976, 72:248-254.

19. Reen DJ: Basic Protein and Peptide Protocols: CHAPTER 47 Enzyme-Linked immunosorbent Assay (ELISA). Totowa, NJ: Humana Press Inc.; 1994

20. Keeley KJ, Schmaman A, Scott A: Definitive diagnosis of amoebic liver abscess: value of liver biopsy. Br Med J 1962, 1:375-376.

21. Tsutsumi V, Mena-Lopez R, Anaya-Velazquez F, Martinez-Palomo A: Cellular bases of experimental amebic liver abscess formation. Am J Pathol 1984, 117:81-91.

22. Fotedar R, Stark D, Beebe N, Marriott D, Ellis J, Harkness J: Laboratory diagnostic techniques for Entamoeba species. Clin Microbiol Rev 2007. 20:511-532. table of contents.

23. Haque R, Mollah NU, Ali IK, Alam K, Eubanks A, Lyerly D, Petri WA Jr: Diagnosis of amebic liver abscess and intestinal infection with the TechLab Entamoeba histolytica II antigen detection and antibody tests. J Clin Microbiol 2000, 38:3235-3239.

24. Parija SC, Khairnar K: Detection of excretory Entamoeba histolytica DNA in the urine, and detection of E. histolytica DNA and lectin antigen in the liver abscess pus for the diagnosis of amoebic liver abscess. BMC Microbiol 2007, 7:41.

25. Zeehaida M, Wan Nor Amilah WA, Amry AR, Hassan S, Sarimah A, Rahmah $\mathrm{N}$ : A study on the usefulness of Techlab Entamoeba histolytica II antigen detection ELISA in the diagnosis of amoebic liver abscess (ALA) at Hospital Universiti Sains Malaysia (HUSM), Kelantan, Malaysia. Trop Biomed 2008, 25:209-216.

26. Valenzuela O, Ramos F, Morán P, González E, Valadez A, Gómez A, Melendro El, Ramiro M, Muñoz O, Ximénez C: Persistence of secretory antiamoebic antibodies in patients with past invasive intestinal or hepatic amoebiasis. Parasitol Res 2001, 87:849-852.

27. Haghighi A, Rezaeian M: Detection of serum antibody to Entameba histolytica in various population samples of amebic infection using an enzyme-linked immunosorbent assay. Parasitol Res 2005, 97:209-212.

28. Shenai BR, Komalam BL, Arvind AS, Krishnaswamy PR, Rao PV: Recombinant antigen-based avidin-biotin microtiter enzyme-linked immunosorbent assay for serodiagnosis of invasive amebiasis. J Clin Microbiol 1996, 34:828-833.

29. Tachibana H, Cheng XJ, Masuda G, Horiki N, Takeuchi T: Evaluation of recombinant fragments of Entamoeba histolytica Gal/GalNAc lectin 
intermediate subunit for serodiagnosis of amebiasis. J Clin Microbio/ 2004, 42:1069-1074.

30. Pal S, Sengupta K, Manna B, Sarkar S, Bhattacharya S, Das P: Comparative evaluation of somatic \& excretory-secretory antigens of Entamoeba histolytica in serodiagnosis of human amoebiasis by ELISA. Indian J Med Res 1996, 104:152-156.

31. Sathar MA, Bredenkamp BL, Gathiram V, Simjee AE, Jackson TF: Detection of Entamoeba histolytica immunoglobulins $\mathrm{G}$ and $\mathrm{M}$ to plasma membrane antigen by enzyme-linked immunosorbent assay. J Clin Microbiol 1990, 28:332-335.

32. Zhou M, Conrads TP, Veenstra TD: Proteomics approaches to biomarker detection. Brief Funct Genomic Proteomic 2005, 4:69-75.

33. Ortner S, Binder M, Scheiner O, Wiedermann G, Duchene M: Molecular and biochemical characterization of phosphoglucomutases from Entamoeba histolytica and Entamoeba dispar. Mol Biochem Parasitol 1997, 90:121-129.

34. Flores BM, Reed SL, Ravdin Jl, Torian BE: Serologic reactivity to purified recombinant and native 29-kilodalton peripheral membrane protein of pathogenic Entamoeba histolytica. J Clin Microbiol 1993, 31:1403-1407.

35. Kaur U, Sharma AK, Sharma M, Vohra H: Distribution of Entamoeba histolytica Gal/GalNAc lectin-specific antibody response in an endemic area. Scand J Immunol 2004, 60:524-528.

36. Sanuki J, Nakano K, Tokoro M, Nozaki T, Okuzawa E, Kobayashi S, Asai T: Purification and identification of major soluble $40-\mathrm{kDa}$ antigenic protein from Entamoeba histolytica: its application for serodiagnosis of asymptomatic amebiasis. Parasitol Int 2001, 50:73-80.

37. Abd-Alla MD, Jackson TF, Reddy S, Ravdin Jl: Diagnosis of invasive amebiasis by enzyme-linked immunosorbent assay of saliva to detect amebic lectin antigen and anti-lectin immunoglobulin $\mathrm{G}$ antibodies. J Clin Microbiol 2000, 38:2344-2347.

38. Lee J, Park SJ, Yong TS: Serodiagnosis of amoebiasis using a recombinant protein fragment of the $29 \mathrm{kDa}$ surface antigen of Entamoeba histolytica. Int J Parasitol 2000, 30:1487-1491.

39. Stanley SL Jr, Jackson TF, Reed SL, Calderon J, Kunz-Jenkins C, Gathiram V, Li E: Serodiagnosis of invasive amebiasis using a recombinant Entamoeba histolytica protein. JAMA 1991, 266:1984-1986.

doi:10.1186/1471-2334-13-144

Cite this article as: Ning et al: Evaluation of Entamoeba histolytica recombinant phosphoglucomutase protein for serodiagnosis of amoebic liver abscess. BMC Infectious Diseases 2013 13:144.

\section{Submit your next manuscript to BioMed Central and take full advantage of:}

- Convenient online submission

- Thorough peer review

- No space constraints or color figure charges

- Immediate publication on acceptance

- Inclusion in PubMed, CAS, Scopus and Google Scholar

- Research which is freely available for redistribution

Submit your manuscript at www.biomedcentral.com/submit
(O) BioMed Central 